\title{
Histological Study of the Possible Protective Effect of Royal Jelly on Ulcerative Colitis Induced by Dextran Sodium Sulfate in Adult Male Albino Rat
}

\author{
NOOR EL-HODA M. ABDINE, M.Sc.; AMAL A. ABD EL-HAFEZ, M.D.; EBTSAM F. OKASHA, M.D. and
}

NADIA F. ABO HASSAN, M.D.

The Department of Histology, Faculty of Medicine, Tanta University, Tanta, Egypt

\begin{abstract}
Background: Ulcerative colitis is a major health problem and its occurrence is progressively increasing around the world. Royal Jelly is widely used up in diets all over the world due to its beneficial effects: Antioxidant, antitumor and anti-inflammatory.
\end{abstract}

Aim: This work aimed to investigate whether an oral pretreatment with Royal Jelly would have any effect on rats submitted to ulcerative colitis using different histological techniques.

Material and Methods: Thirty adult male albino rats were divided into control, Royal Jelly (RJ) (received $100 \mathrm{mg} / \mathrm{kg} /$ day royal jelly orally for two weeks), Dextran Sodium Sulfate (DSS) (received orally $5 \mathrm{ml}$ DSS $5 \%$ daily for seven days for induction of ulcerative colitis) and (DSS \& RJ) (received royal jelly 7 days before induction of ulcerative colitis and continued during the induction period) groups. Colon specimens were processed for light and electron microscopic examinations. Quantitative assessment and statistical analysis were done for the mean number of goblet cells and the mean color intensity of cyclooxygenase 2 (COX 2).

Results: Light microscopic examination of DSS group revealed desquamated epithelial cells, erosions, heavy mononuclear cellular infiltration, dilated congested vessels and abnormal shaped crypts. Statistical results revealed significant decreased goblet cell number and significant increased color intensity of COX-2 immune reaction in comparison to control group. Electron microscopic examination revealed shrunken cells, focal loss of microvilli, widening of intercellular spaces, cytoplasmic vacuolation, irregular nuclei and inflammatory cellular infiltration. DSS \& RJ group revealed preserved mucosal architecture, statistically nonsignificant difference in mean goblet cell number but significant increase in color intensity of COX-2 immune reaction in comparison to control group.

Conclusion: Royal jelly reduced histological alterations in induced ulcerative colitis.

Correspondence to: Dr. Noor El-Hoda M. Abdine, The Department of Histology, Faculty of Medicine, Tanta University, Tanta, Egypt
Key Words: Ulcerative colitis - Dextran sodium sulfateRoyal jelly - Rat.

\section{Introduction}

THE incident of Ulcerative Colitis (UC) is progressively increasing around the globe [1]. Ulcerative colitis being a mucosal disease can extent to entire colon or controlled up to a part of the colon, inducing in erythmatous to haemorrhagic, granular mucosa with certain extensions to terminal colon forming the backwash ileitis [2,3]. UC is characterized by an uneven damage to the intestinal mucosa resulting from multiple etiologies including genetic, environmental, microbial and immune inflammatory mediators $[4,5]$.

The most troubling symptoms and consequences of UC are ulceration, loss of blood through fecal matter, abdominal pain, diarrhoea, loss of body weight, loss of minerals from the bones and osteoporosis [6,7]. UC induce increased energy spending and nutritional deficiencies like malnutrition, malabsorption, disturbed digestion, loss of gastrointestinal proteins [8]. The treatment objectives for UC include prevention and treatment of complications and reestablishment of nutritional deficits to improve patient's quality of life.

The anti-inflammatory drugs include immunosuppressants, biologic agents, antibiotics, and drugs to suppress inflammatory responses and to relieving symptoms are used in treatment of UC. The Complementary and alternative therapies are also considered to be effective in treatment of UC however, there is a need for well-planned preclinical and clinical investigations to supports such claims [9]

Royal Jelly (RJ) is a secretion rich in protein and lipids produced by the hypopharyngeal and 
mandibular glands of Appis mellifera L. young worker honeybees (called nurses). It is composed of water, carbohydrate, lipids, proteins, vitamins (mainly riboflavin, niacin, and thiamin) and some minerals (mainly calcium and iron). Due to its high content of bioactive compounds, RJ exhibits lots of health-promoting properties, such as antibacterial, antioxidant, anti-inflammatory, vasodilator, hypotensive, hypocholesterolemic, hepatoprotective, and antitumor activity [10,11]

An important limitation in experiencing therapies is the difficulty of the patient to leave his therapy and experience another one like royal jelly. However, in recent years a large number of animal models have been developed. These models have greatly advanced our knowledge about the pathophysiology of the diseases and allowed the chance for therapy trials [12].

To our knowledge, no precise analysis has yet been performed of the efficacy of royal jelly in reducing DSS-induced ulcerative colitis in rat. So, in present investigation is substantiated.

In experimental acute colitis that is induced in rodents by feeding them DSS, the clinical and histopathological results are similar to that of human ulcerative colitis. This model is simple and is frequently used in studying the role of innate immune mechanisms in the development of mucosal inflammation and the re-establishment of barrier integrity $[\mathbf{1 3 , 1 4 ]}$.

Since there is no curative drug has been developed yet for treatment of UC, new and alternative therapies arise to avoid complications and improve the patients' health status. The aim of this work was to study the possible protective effect of royal jelly on DSS induced ulcerative colitis in adult male albino rat by using different histological techniques.

\section{Material and Methods}

This work was carried out from January 2017 till August 2017 at Histology Department, Faculty of Medicine, Tanta University and at The Electron Microscopic Unit, Faculty of Agriculture, Mansoura University.

\section{Experimental animals:}

This work was carried out on 30 adult male albino rats, their weights ranged between 100 and 150 grams. All the animals were housed in suitable clean properly ventilated cages under similar conditions and were fed on a similar commercial laboratory diet and water [15]. They were acclima- tized to their environment at least one week before starting the experiment.

\section{Animals were divided into four groups:}

I- Control group: Was formed of 10 rats received no medications and used for histological study of the control colonic tissue.

II- Royal Jelly group (RJ): Was formed of 5 rats and given royal jelly orally once daily for two weeks.

III- Dextran Sodium Sulfate group (DSS): Was formed of 5 rats and given 5\% DSS solution for seven days to induce ulcerative colitis.

$I V$ - Dextran sodium sulfate and royal jelly group (DSS \& RJ): Was formed of 10 rats received royal jelly 7 days before induction of ulcerative colitis and continued during the period of induction.

\section{Chemicals:}

Dextran Sodium Sulfate (DSS) 5\% was used for induction of ulcerative colitis in rats. It was purchased from Sigma Company, Cairo (Egypt) in the form of white odorless powder with a molecular weight 40,000 . DSS $5 \%$ solution was prepared by adding $25 \mathrm{~g}$ of DSS powder to $500 \mathrm{~mL}$ of distilled water and left as stock solution at $4^{\circ} \mathrm{C}$ until use. The dose was $5 \mathrm{ml} / \mathrm{rat} /$ day orally using a gastric tube for 7 days (so each $5 \mathrm{ml}$ of the prepared stock solution contained about $0.25 \mathrm{mg} / \mathrm{rat}$ ) [13]

Royal Jelly was used for studying its possible protective effect on ulcerative colitis. It is manufactured by PHARCO Pharmaceuticals Alexandria (Egypt), in the form of soft gelatin capsules, each contains royal jelly lyophilized $340 \mathrm{mg}$ equivalent to natural royal jelly $1000 \mathrm{mg}$. The used dose was $100 \mathrm{mg} / \mathrm{kg} /$ day (each capsule is emptied and dissolved in $40 \mathrm{ml}$ of distilled water, so each $0.5 \mathrm{ml}$ of the prepared solution contained about $12 \mathrm{mg}$ ). Rats were given $0.5 \mathrm{ml}$ of the prepared solution orally once daily using a gastric tube for 14 days [16]

At the appropriate time, twenty-four hours after the last dose, rats were scarificed under anesthesia by diethyl ether inhalation [17]. The abdominal wall of each rat was opened to make a midventral incision along the entire length of the abdominal cavity exposing the viscera. About five $\mathrm{cm}$ of distal colon was resected; $0.5 \mathrm{~cm}$ proximal to the anus, rinsed in saline for clearing of colonic content, and divided into 3 segments. The first segment was cut for longitudinal sections and the second for transverse sections and both were processed for light microscopic examination. The third segment was processed to prepare semithin and ultrathin sections for electron microscopic examination. 
Preparation of specimens for light microscopic studies:

Routine and PAS histological examination: The first and second segments were taken and immediately fixed in $10 \%$ formol saline solution for 24 hours. Then dehydrated in ascending grades of ethyl alcohol and cleared in two changes of xylol 30 minutes each. Impregnation was done in pure soft paraffin for 2 hours at $60^{\circ} \mathrm{C}$ followed by embedding in hard paraffin. Finally, sections of 5um in thickness were cut for $\mathrm{H} \& \mathrm{E}$ routine histological examination and PAS for detection of mucopolysaccharides [18]

Immunohistochemical study (COX 2): 5um paraffin sections were taken on charged slides, dried overnight at $60^{\circ} \mathrm{C}$, dewaxed, rehydrated and heated to induce epitope retrieval. Sections were boiled in EDTA buffer PH 8 for $20 \mathrm{~min}$ at $95^{\circ} \mathrm{C}$. They were rinsed in distilled water followed by cooling at room temperature. Endogenous peroxidase block was added at room temperature using peroxidase solution followed by rabbit anti-human COX 2 (cyclooxygenase 2) monoclonal antibody (clone SP21) obtained from Master Diagnostica diluted 1:50 applied to sections then incubated for $10 \mathrm{~min}$. Detection System (DAB included) was used for detection of reaction then counterstaining with haematoxylin and final mounting of the slides were performed. Negative control slides were prepared by the same procedure but without adding the primary antibody [18]. This procedure used was also performed according to the manufacturer's instructions (Master Diagnostica, www. masterdiagnostica.com) for detection of cyclooxygenase 2.

Preparation of specimens for electron microscopic studies:

The specimens were fixed in $2.5 \%$ phosphate buffered glutaraldehyde, processed and embedded in epoxy resin by routine protocol. Semithin sections (1 ick) were stained with toluidine blue and examined to choose the part to be studied by TEM. Ultrathin sections of ( $75 \mathrm{~nm}$ thick) were picked upon 200 mesh uncoated copper grids, stained with uranyl acetate and counter-stained with lead citrate to be examined by JEOL-JEM2100 electron microscope with Gatan microscopy suite camera at the Electron Microscopic Unit, Faculty of Agriculture, Mansoura University [18]

Quantitative assessment and statistical analysis:

A- The mean number of goblet cells:

PAS-stained goblet cells were counted under a high magnification power X400 of the light micro- scope in ten non overlapped fields for each group. This was done using Olympus light microscope in Histology Department, Faculty of Medicine, Tanta University.

\section{B- The mean color intensity of cyclooxygenase 2} (COX 2):

The image analysis software program (Image J. 1.48 version) was used to measure color intensity of COX 2 immunoreaction in 10 non overlapped fields for each specimen at a magnification power of (X1000).

All the previous data were statistically analyzed using SPSS software Version 13 (SPSS Inc., Chicago, IL, USA), then compared by one way analysis of variance (ANOVA) test followed by Tukey's test to compare different groups with the control group and the results were expressed as mean \pm Standard Deviation (SD). The differences were considered statistically significant if probability value $p<0.05$ and highly significant if $p<0.001$ and non-significant if $p>0.05$ [19] .

\section{Results}

Histological results:

A- Light microscopic study:

I- Haematoxylin and eosin stained sections:

Control Group (I): Examination of haematoxylin $\&$ eosin stained sections obtained from colon of control group showed the characteristic histological picture which was identical to known histological structure of the colon. The wall of colon was composed of mucosa, submucosa, musculosa and serosa. The surface and glandular lining epithelium showed simple columnar absorptive cells with oval basal nuclei, apical brush border and acidophilic cytoplasm, while the goblet cells showed apical expanded and basal compressed parts containing nuclei. Lamina propria showed few mononuclear cells filling the space between the closely packed simple tubular straight glands parallel to each other Figs. (1A,B).

RJ Group (II): Examination of sections obtained from the colon of this group revealed the same histological picture of the colon as in the control group Figs. (1C,D).

DSS Group (III): Examination of sections obtained from the UC colon of rats revealed changes of different degrees of inflammation which were focal in some sections and diffuse in others and were variable from rat to other. These changes were in the form of loss and desquamation of surface epithelial cells, most of which showed dark 
pyknotic nuclei, apparent decrease in the number of goblet cells and inflammatory cellular infiltration with dilated blood vessels in the lamina propria. There were also disorganized mucosal architecture and abnormal shaped crypts with formation of cyst like structure and some of them contained desquamated goblet cells. Submucosa was apparently thickened with presence of dilated congested blood vessels Figs. (2A-D).

DSS \& RJ Group (IV): Examination of sections obtained from the colon of rats of this group revealed more or less preservation of the normal histological structure of the colon. Intact surface epithelial lining, number of goblet cell was more or less like control and the mucosal glands were long straight and parallel to each other. Few inflammatory cellular infiltrations were observed in the lamina propria Figs. (3A,B).

\section{II- Periodic Acid Schiff (PAS) stained sections:}

Examination of PAS stained sections obtained from the control Group I revealed intact PAS positive thin brush border of columnar cells. Goblet cells were abundant with its magenta red color Fig. (4A). PAS stained sections of Group II were similar to control group Fig. (4B). On the other hand, PAS stained sections obtained from Group III revealed thin interrupted brush border and apparent decrease in the number of goblet cells Fig. (4C). However, PAS stained sections obtained from Group IV revealed intact thin brush border and goblet cells appeared magenta red and regained the number so became more or less like control group Fig. (4D).

\section{III- Immunohistochemical results:}

\section{Cyclooxygenase-2 (COX-2):}

Examination of negative control sections revealed absence of immune reaction in colonic tissue Fig. (5), while Group I \& II revealed apparent weak COX-2 positive cytoplasmic immune reaction in both columnar and goblet cells Figs. (6A,B). On the other hand, examination of sections obtained from Group III revealed strong positive reaction in surface and glandular epithelial cells Fig. (6C). Examination of Group IV revealed apparent weak immune reaction in most columnar and goblet cells alternating with focal strong positive cytoplasmic reaction in some cells Fig. (6D).

\section{$I V$ - Semithin sections (Toluidine blue stained):}

Semithin sections of colonic mucosa of Group I \& II showed simple columnar cells with basal oval pale-stained nuclei with occasional prominent nucleoli. Goblet cells appeared with apical extended portion containing mucin that stained from pink to deep blue and narrow basal portions containing nuclei Figs. (7A,B). Semithin sections of Group III showed disturbed mucosal architecture with distortion of glands and most of their cells showed dark stained nuclei with appearance of giant cells Fig. (7C). On the other hand, semithin sections of Group IV showed preserved shape of colonic glands, the surface epithelial lining of columnar cells with basal oval pale nuclei and goblet cells with apical distended parts and basal narrow parts Fig. (7D).

\section{B- Electron microscopy study:}

Examination of ultrathin sections obtained from colon of Group I revealed regularly arranged columnar cells with basal oval euchromatic nuclei and closely packed regularly arranged microvilli Fig. (8A). The columnar cells were connected to each other by junctional complexes Fig. (8B). Goblet cell was detected in between the columnar cells with distended apical part containing mucin granules and compressed basal part containing the nucleus and cell organelles mainly rER Fig. (8C). Examination of ultrathin sections of Group II showed the same ultrastructure of cells lining colon as in the control group Fig. (8D).

On the other hand, examination of ultrathin sections of Group III showed electron dense shrunken columnar cells with cytoplasmic vaculations, wavy outline and wavy basement membrane Fig. (9A). Columnar cells appeared with indented nuclei and dilated perinuclear spaces while goblet cell revealed an electron dense indented nucleus and dilated rER Fig. (9B). Lamina propria revealed widely separated fibroblast like cells with apparently deposition of collagen and cellular infiltration mainly plasma cells and eosinophils Figs. (9C,D).

Examination of ultrathin sections of Group IV revealed majority of columnar cells appeared with regularly arranged microvilli and basal rounded to oval euchromatic nuclei. Goblet cells were seen with distended apical parts with mucin granules and compressed basal part containing nuclei Fig. (10A). Few columnar cells appeared with cytoplasmic vacuoles, focal loss of apical microvilli and intercellular spaces were mildly dilated Figs. $(10 B, C)$. Cellular infiltration was observed in the lamina propria between the cells Fig. (10D).

Quantitative assessment and statistical analysis:

A- Statistical results for the mean number of goblet cells:

As assessed by Olympus light microscope in Histology Department, Tanta University. Group II 
revealed nonsignificant difference in the mean number of goblet cells compared with control group. Group III showed statistically highly significant decrease in the mean number of goblet cells compared with control group and Group IV, while Group IV showed nonsignificant difference in the mean number of goblet cells compared with control group. All these data were illustrated in (Table 1) and Histogram (1).

B- Statistical results for the mean color intensity of cyclooxygenase 2 (COX 2) immunohistochemistry:

As assessed by the image analysis software program (image J. 1.48 Version), Group II revealed nonsignificant difference in the mean color intensity of COX2 immunohistochemistry compared with control group. Group III showed highly significant increase in the mean color intensity of COX2 immunohistochemistry compared with all other groups. Group IV showed significant increase in the mean color intensity of COX 2 immunohistochemistry compared with control group and nonsignificant difference compared with group II. All these data were illustrated in (Table 2) and Histogram (2).
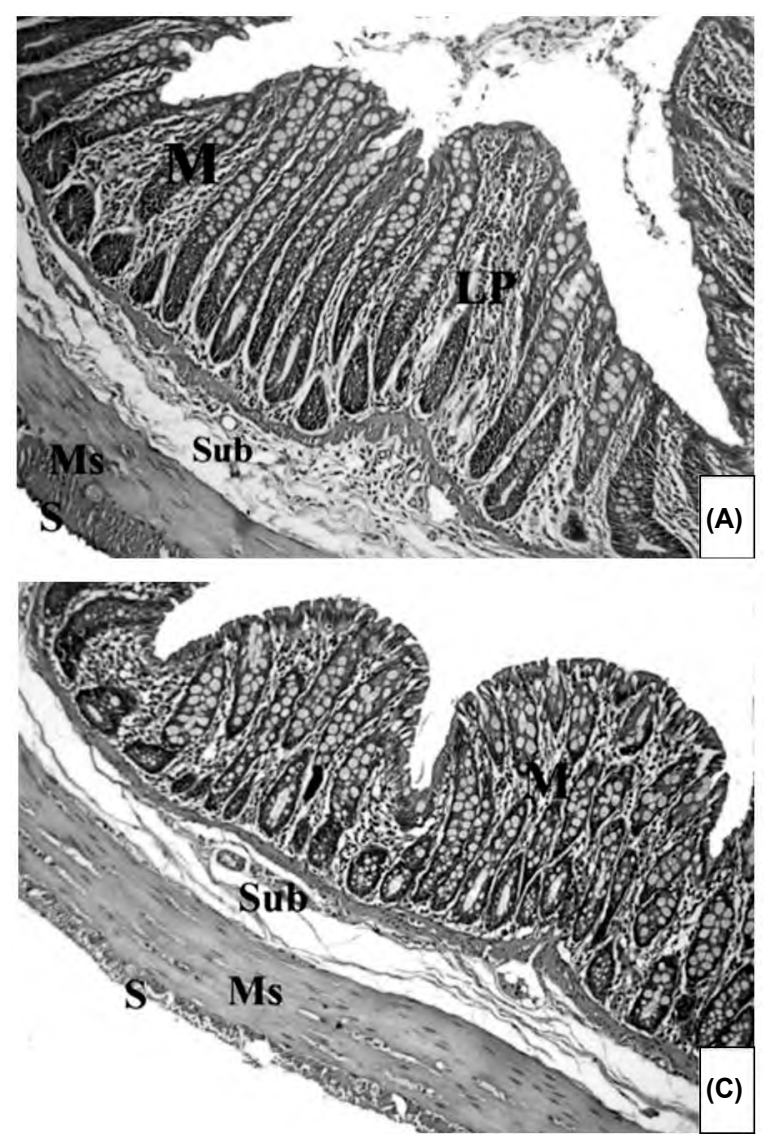

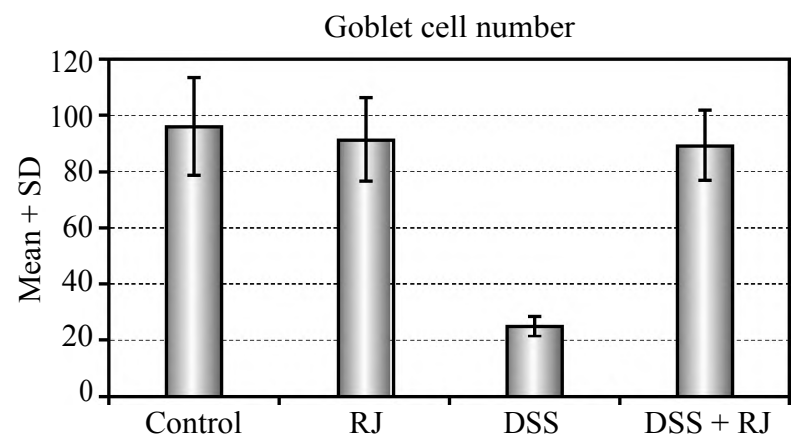

Histogram (1): Mean number of goblet cells in different studied groups.

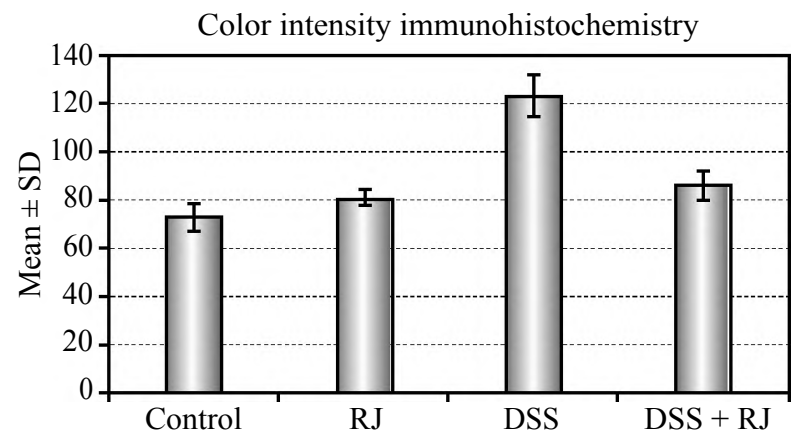

Histogram (2): Mean color intensity of COX2 immunohistochemistry in different studied groups.
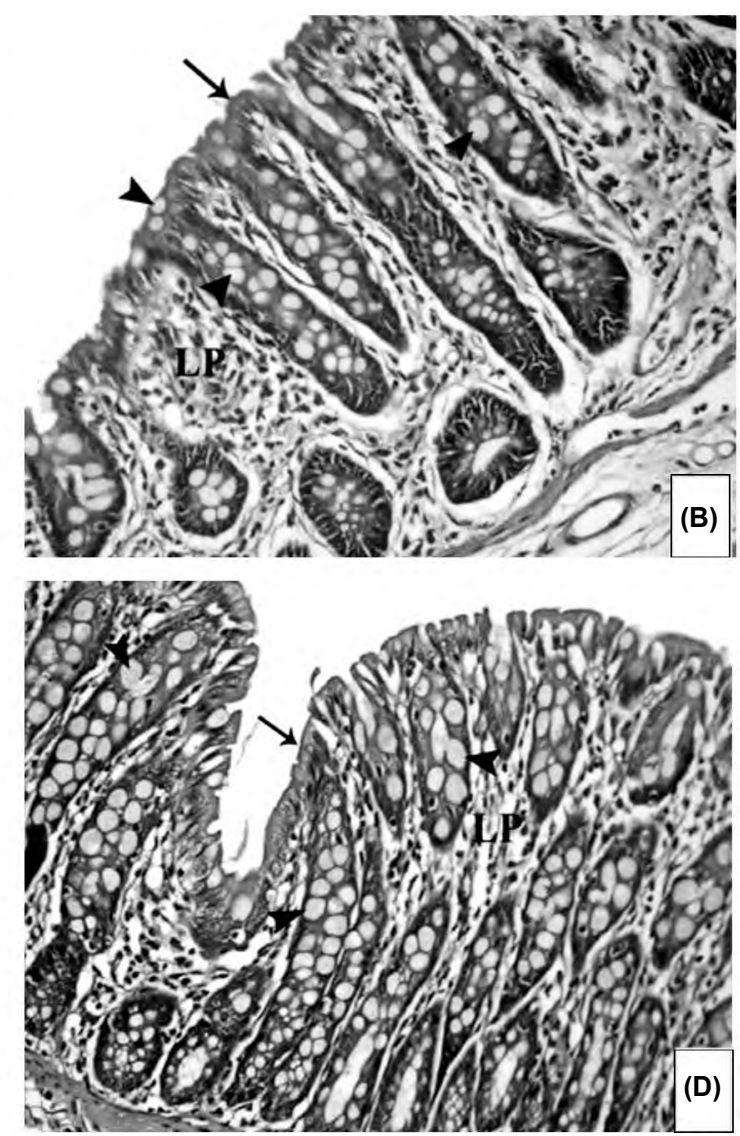

Fig. (1): Photomicrographs for colon of Group I, II showing mucosa (M), submucosa (Sub), musculosa (Ms) and serosa (S). Lamina Propria (LP) contains closely packed simple tubular glands parallel to each other lined with simple columnar cells (arrow) and goblet cells (arrow head) (H \& E, 1A,C X200 \& 1B,D X400). 

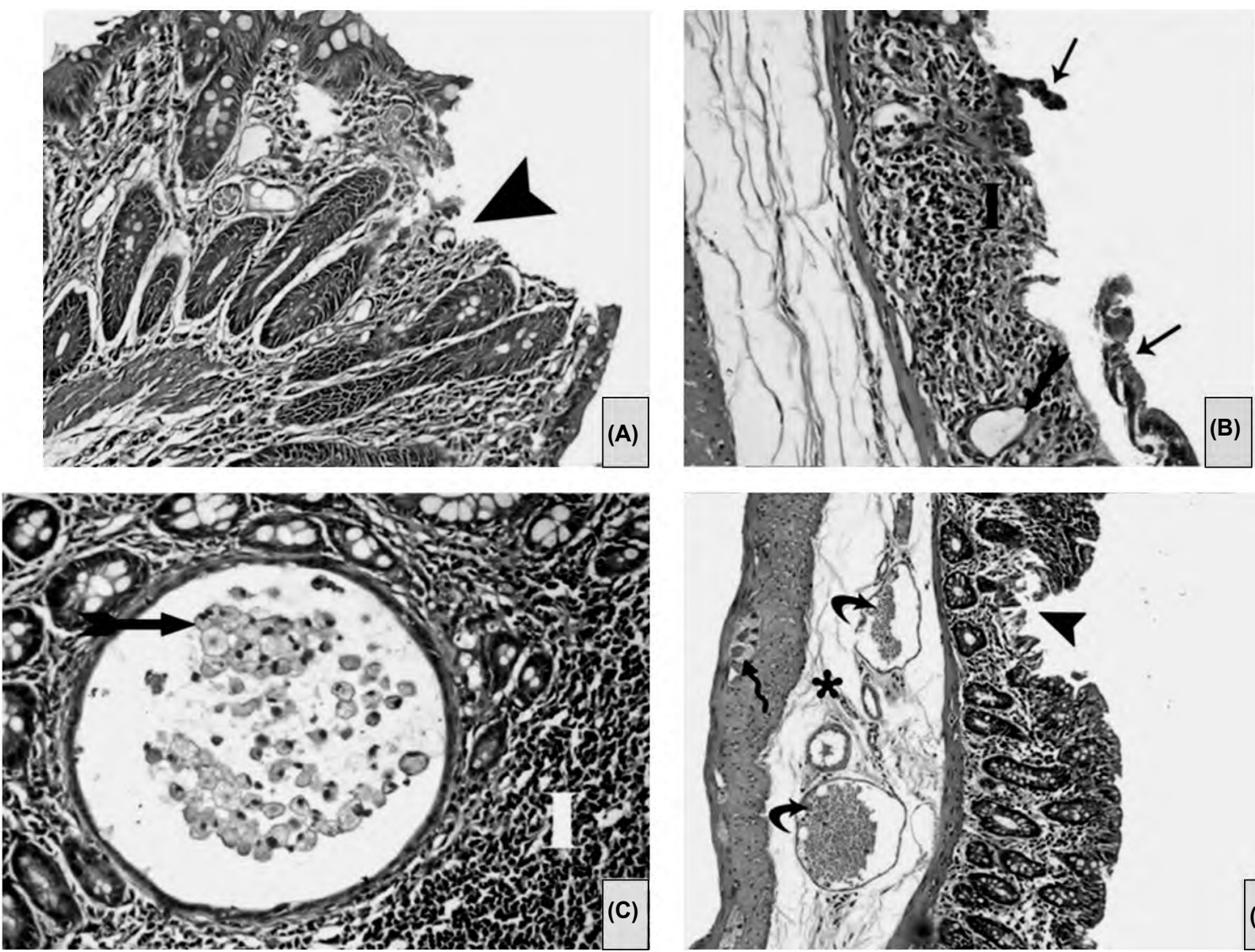

Fig. (2): Photomicrographs for colon of Group III showing focal loss of surface epithelium and part of the lamina propria (2A), desquamation of surface epithelial cells (arrow), disorganized mucosal architecture. Most of epithelial cells are seen with pyknotic nuclei and apparent decrease in number of goblet cells. Inflammatory cellular infiltration (I) in the lamina propria and formation of crypt cyst (bifid arrow) (2B), some cysts contain multiple desquamated goblet cells (bifid arrow) (2C). Apparent thickening of submucosa (asterisk) containing dilated congested blood vessels (curved arrows). Notice myenteric plexus (wavy arrow) between the inner circular and outer longitudinal layers of musclaris externa (2D) (H \& E 2A,B,C X400 \& 2D X200).
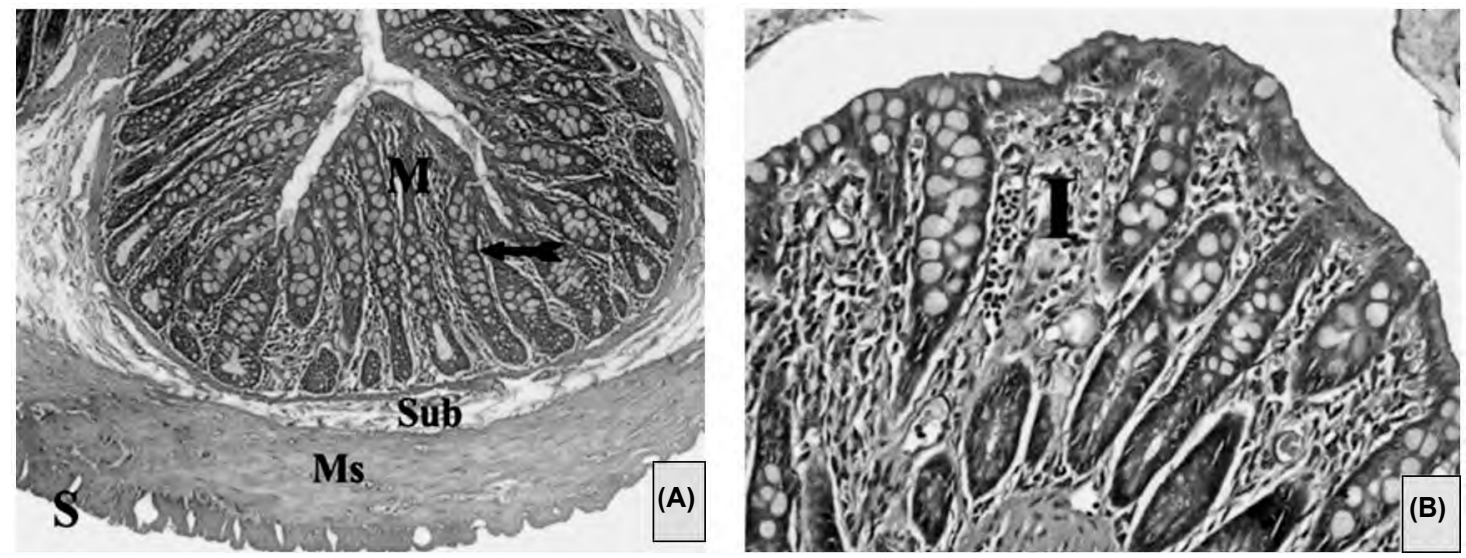

Fig. (3): Photomicrographs for colon of Group IV showing mucosa (M) with its characteristic glands (bifid arrow), submucosa (Sub), musculosa (Ms) and serosa (S). Number of goblet cells becomes more or less as in control group (3A). Inflammatory cellular infiltrations (I) still present in the lamina propria between the glands (3b) (H \& E 3A X200 \& 3B X400). 

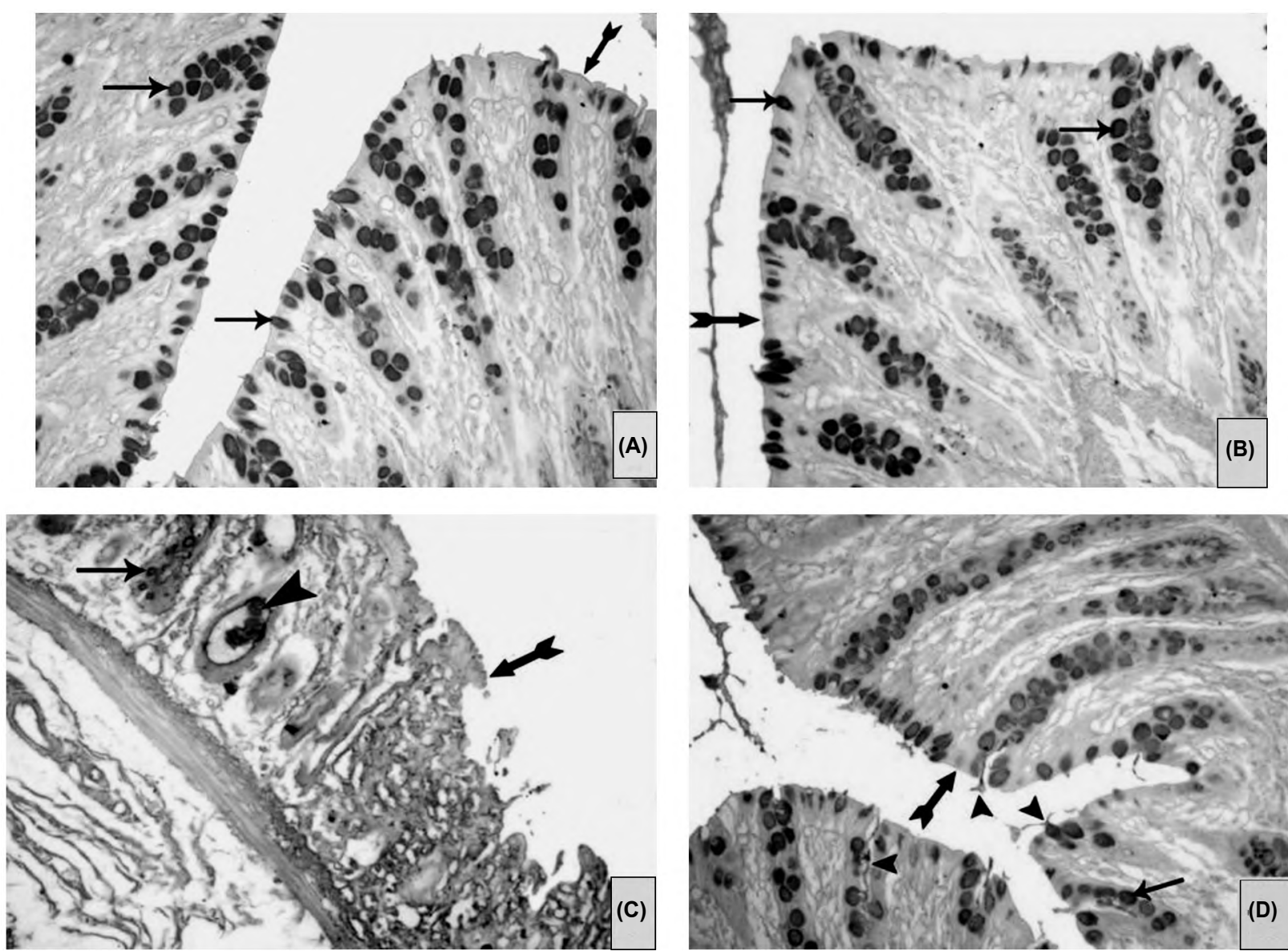

Fig. (4): Photomicrographs for PAS stained sections: Group I \& II showing PAS positive thin brush border (bifid arrow) and goblet cells (arrows) (4A,B). Group III showing thin interrupted brush border (bifid arrow) and apparent decrease in the number of goblet cells (arrow). Notice crypt cyst containing magenta red colored mucin (arrow head) (4C). Group IV showing intact thin brush border (bifid arrow) and goblet cells appeared magenta red (arrow). Notice increased number of goblet cells and secretion of magenta red colored mucin from goblet cells through the crypts (arrow heads) (4D) (PAS 4A,B,C,D X400).

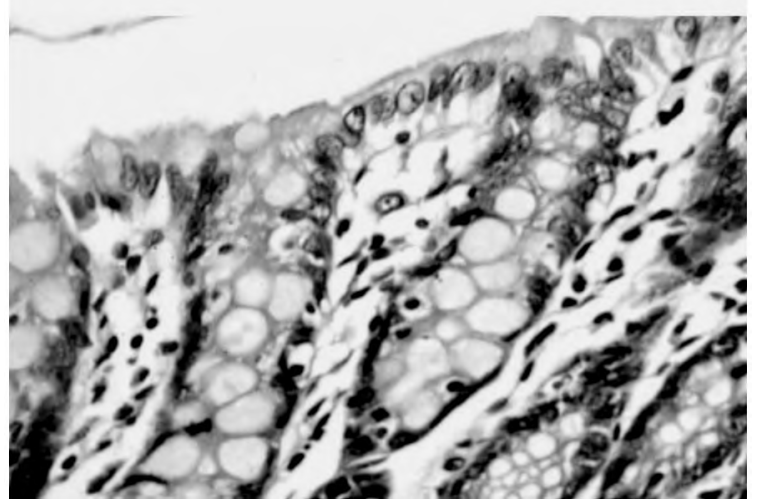

Fig. (5): A photomicrograph of negative control section of colon showing no immune reaction in all cells. (Negative control, Mag. X1000).
Table (1): Mean number of goblet cells in different studied groups.

\begin{tabular}{llllll}
\hline \multirow{2}{*}{ Groups } & \multicolumn{2}{c}{ Goblet cell number } & & \multicolumn{2}{c}{ ANOVA } \\
\cline { 2 - 3 } \cline { 6 - 6 } & Range & Mean $\pm \mathrm{SD}$ & & F & $p$-value \\
\hline Control & $77-116$ & $95.360 \pm 17.118$ & & $33.410<0.001 *$ \\
RJ & $70.7-103.1$ & $91.200 \pm 14.827$ & & \\
DSS & $21.8-29.2$ & $24.680 \pm 3.576$ & & \\
DSS + RJ & $73-104.9$ & $88.880 \pm 12.374$ & & \\
\hline
\end{tabular}

TUKEY'S Test

\begin{tabular}{lccccc}
\hline $\begin{array}{l}\mathrm{C} \& \\
\mathrm{RJ}\end{array}$ & $\begin{array}{c}\mathrm{C} \& \\
\mathrm{DS}\end{array}$ & $\begin{array}{c}\mathrm{C} \& \mathrm{DS} \\
+\mathrm{RJ}\end{array}$ & $\begin{array}{c}\mathrm{RJ} \& \\
\mathrm{DS}\end{array}$ & $\begin{array}{c}\text { RJ \& DS } \\
+\mathrm{RJ}\end{array}$ & $\begin{array}{c}\text { DS \& DS } \\
+\mathrm{RJ}\end{array}$ \\
\hline 0.957 & $<0.001 *$ & 0.859 & $<0.001 *$ & 0.992 & $<0.001 *$ \\
\hline
\end{tabular}



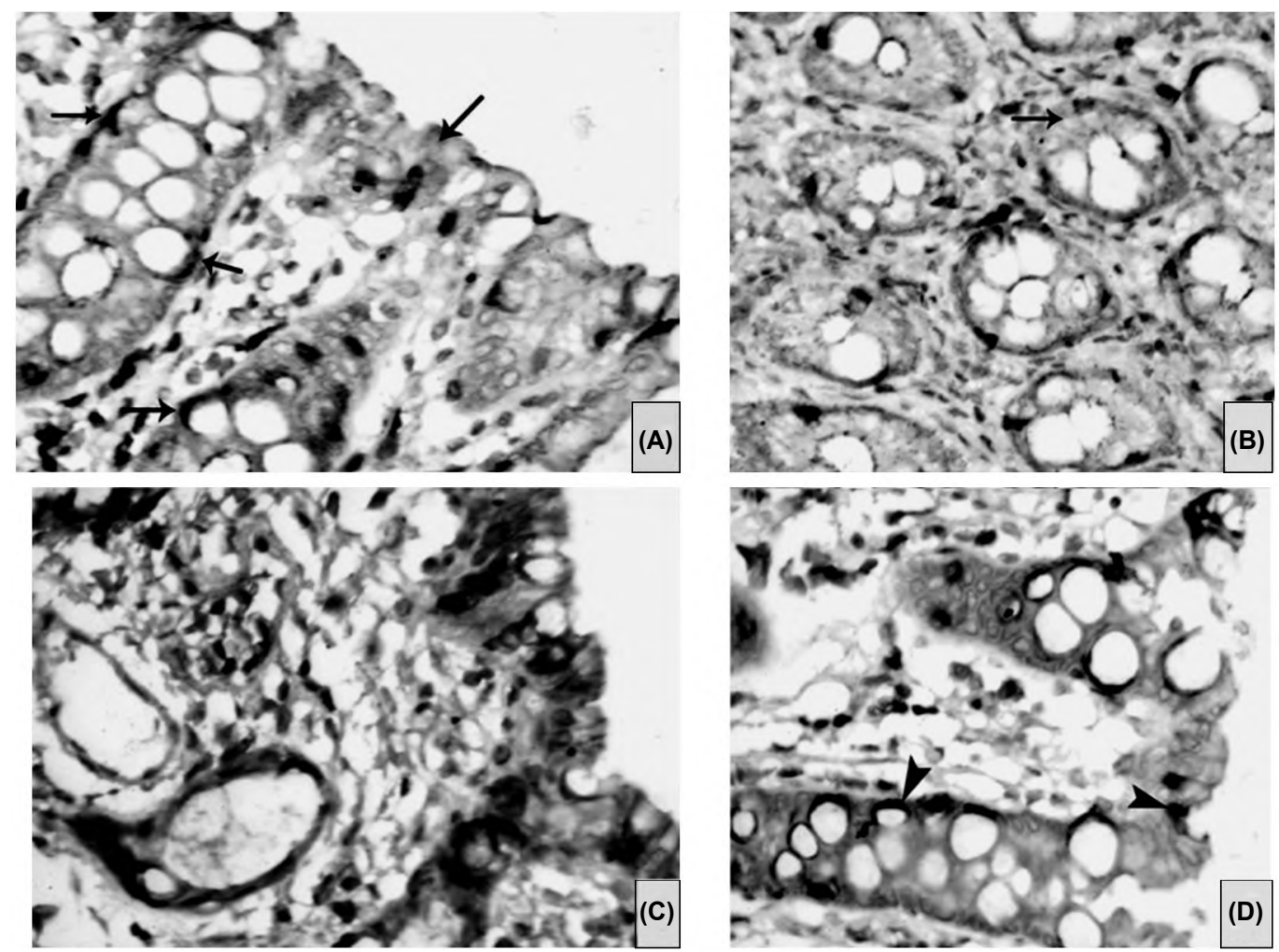

Fig. (6): Photomicrographs for COX-2 immunostained sections: Group I \& II showing apparent weak COX-2 positive cytoplasmic immunoreaction in both columnar epithelial cells and goblet cells (arrows) (A,B). Group III is showing apparent strong COX-2 positive cytoplasmic immunoreaction in both surface and glandular epithelium (C). Group IV is showing weak COX-2 positive cytoplasmic immunoreaction in most columnar and goblet cells with focal strong positive reaction in some cells (arrow heads) (COX-2 immunostaining \& H, 6A,B,C,D X 1000).
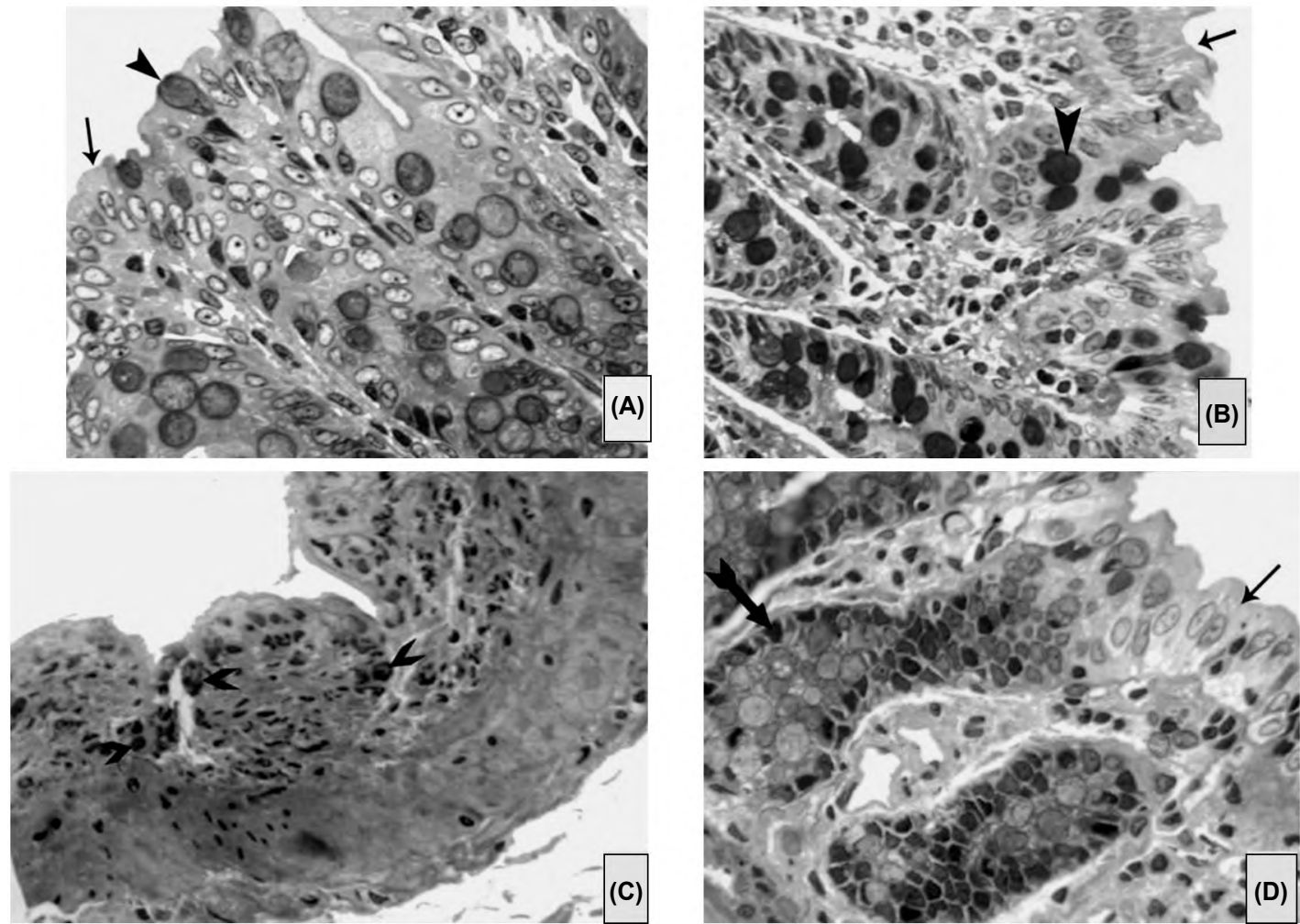

Fig. (7): Photomicrographs for semithin toluidine blue stained sections: Group I \& II showing simple columnar cells (arrow) with basal oval pale-stained nuclei with prominent nucleoli in some of them. Goblet cells (arrow head) appeared with apical extended portions containing mucin stained from pink to deep blue color and narrow basal portions containing the nuclei (A,B). Group III is showing disturbed mucosal architecture with presence of giant cells (arrow heads) (C). Group IV is showing the lining surface epithelium of simple columnar cells that have basal oval and pale nuclei (arrow), while those lining the glands have dark nuclei (bifid arrow) (D) (Toluidine blue, Mic. Mag. X1000). 

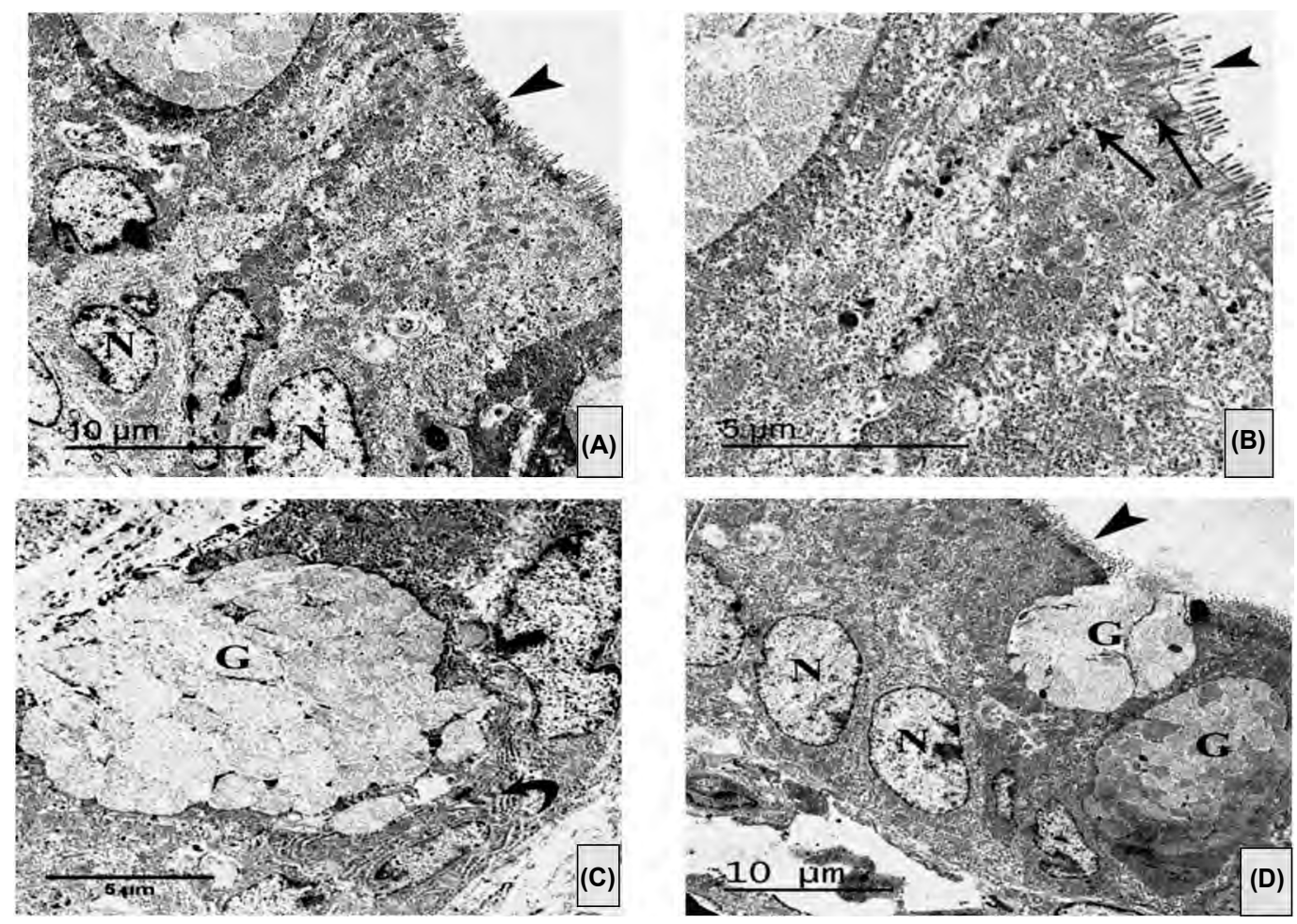

Fig. (8): Electron micrographs for ultrathin sections: Group I \& II showing columnar absorptive cells with apical closely packed regularly arranged microvilli (arrow head) with basal oval euchromatic nuclei $(\mathrm{N})$ and apical junctional complexes (arrows) (A,B). Goblet cell (G) with distended apical part containing mucin granules and compressed basal part containing the nucleus $(\mathrm{N})$ and rER (curved arrow) (C,D).
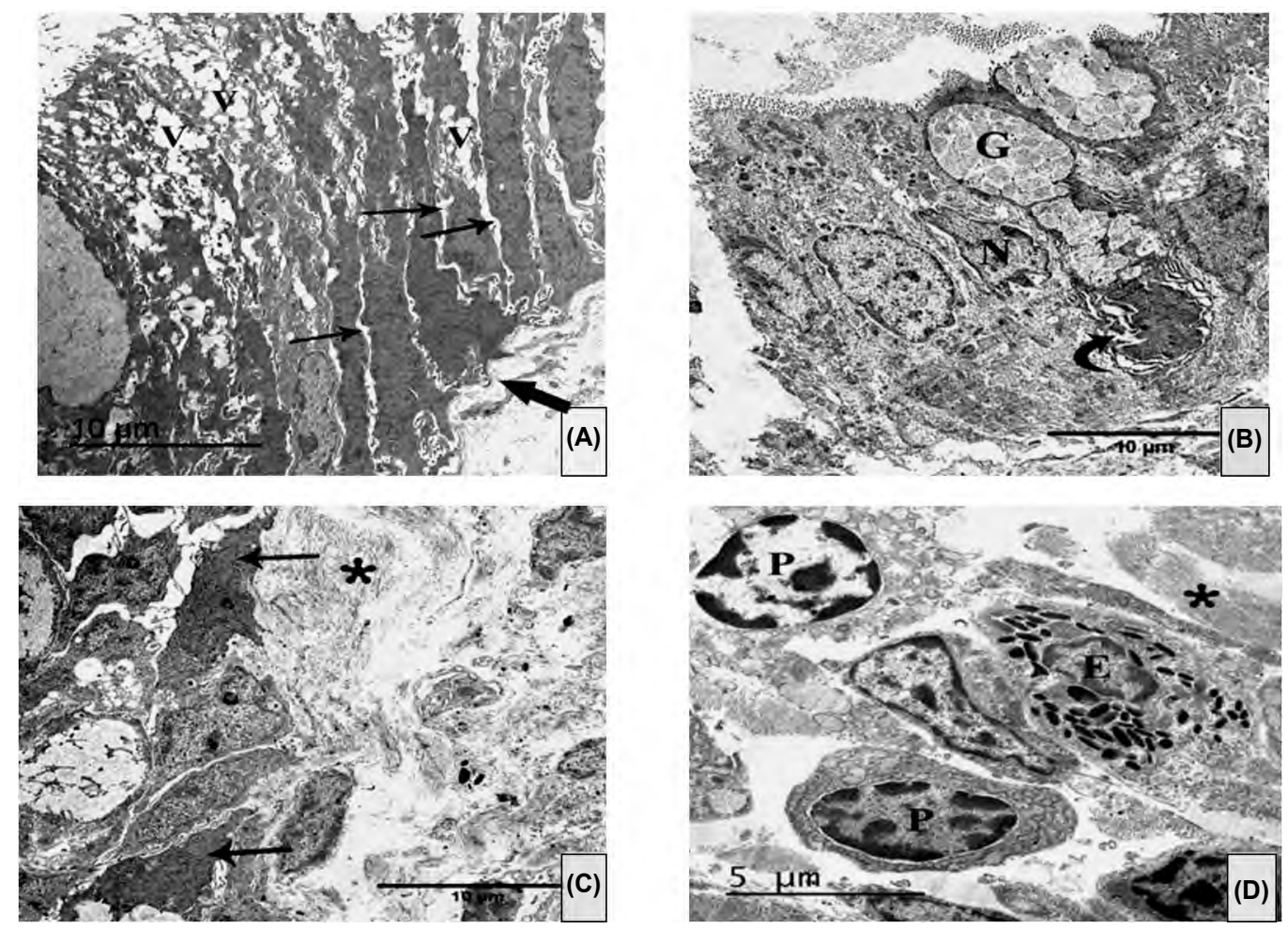

Fig. (9): Electron micrographs for ultrathin sections: Group III showing electron dense shrunken surface columnar epithelial cells with wavy irregular outline (thin arrows) and apical cytoplasmic vaculations (V), notice irregular wavy basement membrane (thick arrows) (A). Goblet cell (G) with electron dense indented nucleus and dilated rER (curved arrow), notice indented nucleus $(\mathrm{N})$ of columnar cell $(\mathrm{B})$. There is widely separated fibroblasts like cells (arrow) with deposition of collagen fibers (asterisk) at the basal aspect of the epithelium (C). Lamina propria showing inflammatory cellular infiltration formed mainly of plasma cells (P) and eosinophil (E) with collagen fibers in between (asterisk) (D). 

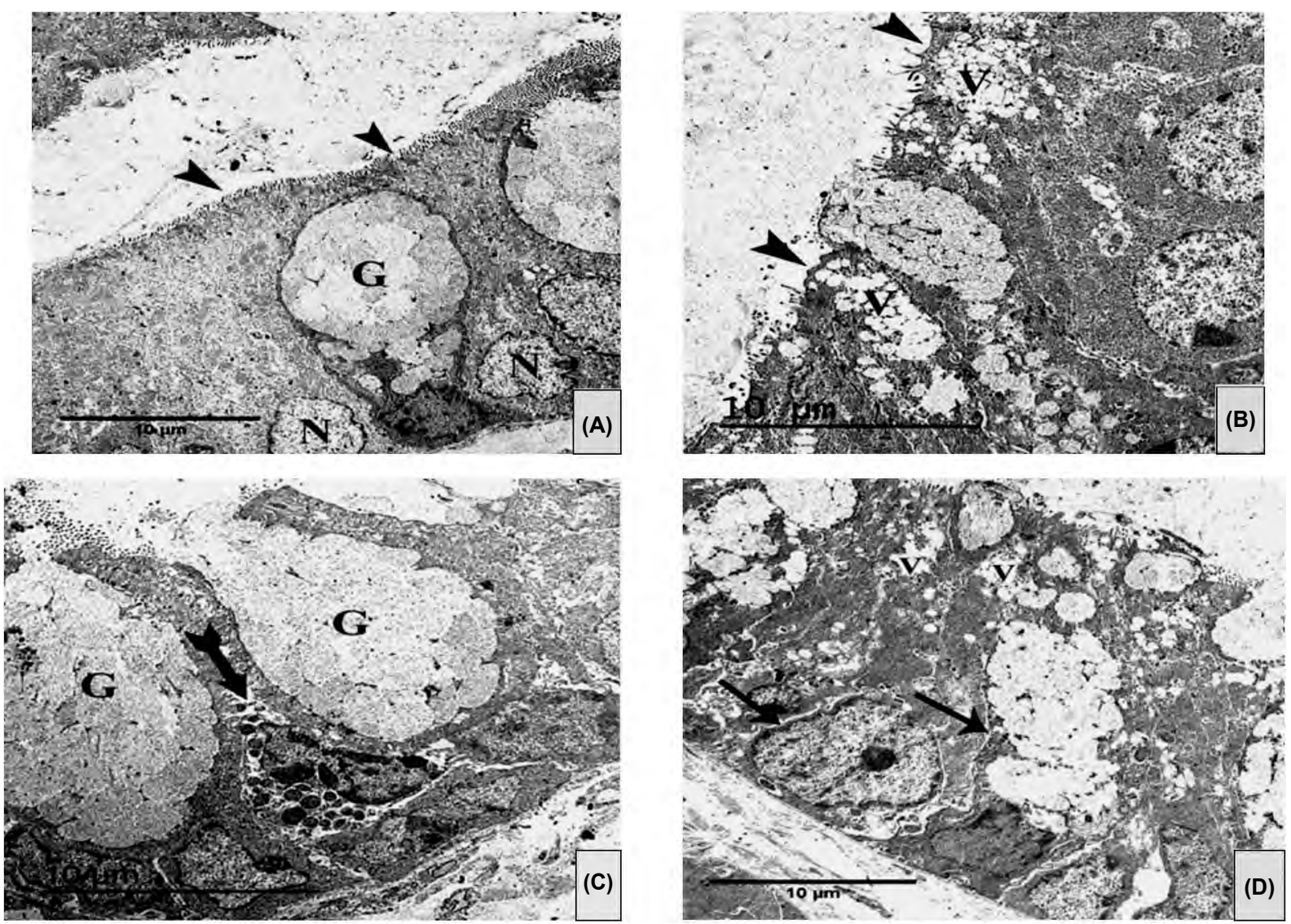

Fig. (10): Electron micrographs for ultrathin sections: Group IV showing columnar cells with preserved microvilli (arrow heads) and basal oval euchromatic nuclei $(\mathrm{N})$. Goblet cell $(\mathrm{G})$ with apical part distended with mucin granules and basal part containing compressed nucleus (A), but some areas are still showing focal loss of microvilli (arrow heads), apical vaculation (V), mild dilated intercellular spaces (arrows) and inflammatory cell infiltration (bifid arrow) most probably mast cell between two goblet cells $(G)(B, C, D)$.

Table (2): Mean color intensity of COX2 immunohistochemistry in different studied groups.

\begin{tabular}{lccccc}
\hline \multirow{2}{*}{ Groups } & \multicolumn{2}{c}{ Color intensity } & \multicolumn{2}{c}{ ANOVA } \\
\cline { 2 - 6 } & Range & Mean \pm SD & F & $p$-value \\
\hline Control & $63.8-77.98$ & $72.588 \pm 5.838$ & 61.444 & $<0.001 *$ \\
RJ & $77.01-85.47$ & $80.412 \pm 3.285$ \\
DSS & $110.87-133.48$ & $122.366 \pm 8.733$ \\
DSS + RJ & $78.11-94.91$ & $85.680 \pm 6.114$ \\
\hline \multicolumn{7}{c}{ TUKEY'S Test } \\
\hline C \& & C \& & C \& DS & RJ \& & RJ \& DS & DS \& DS \\
RJ & DS & + RJ & DS & + RJ & + RJ \\
\hline 0.242 & $<0.001 *$ & $0.022^{*}$ & $<0.001 *$ & 0.562 & $<0.001 *$ \\
\hline
\end{tabular}

\section{Discussion}

The aim of this study is to investigate the possible protective effects of royal jelly on UC rat model as it is important to enhance the quality of life for patients of UC and high risk people by preventing the severity of acute attacks and its complications.
In this study, light microscopic examination of the DSS group revealed histological changes in colonic mucosa in the form of loss of surface epithelium (erosions) which may be due to the direct toxic effect of DSS on intestinal epithelial cells that may end to erosions that ultimately compromise barrier integrity resulting in an increase in the colonic epithelial permeability aggravating inflammation [20-24]. DSS also associates with colonic medium-chain-length fatty acids present abundantly in the chow forming nano-lipo complexes which are absorbed and metabolized by epithelial cells causing epithelial injury [12].

Epithelial cell desquamation observed in this study was attributed to the formation of Reactive Oxygen Species (ROS) in the intestinal mucosa during inflammation leading to disruption of blood vasculature and desquamation of epithelial cells [25].

Dark pyknotic nuclei observed in the surface columnar cells may be due to excessive apoptosis as the gastrointestinal tract is lined by a delicate 
monolayer of epithelial cells characterized by high turnover. So, the maintenance of this epithelial barrier function requires a dynamic balance between epithelial loss by apoptosis and generation of new cells by proliferation. When this balance is shifted towards excessive apoptosis, multiple gastrointestinal diseases can manifest. During DSS-induced colitis tumor necrosis factor (TNF $\alpha$ ) is highly upregulated and it signals via two receptors TNFR1 and TNFRII. Signaling via TNFR1 is associated with apoptosis and cytokine production whereas signaling via TNFRII is associated with proliferation and enhanced cell survival [23].

Heavy inflammatory cellular infiltration associated with dilated, congested blood vessels in the lamina propria and submucosal vascular congestion were observed in this study and other previous studies [26-28]. The inflammatory cellular infiltration may be due to endothelial cell intercellular adhesion molecule-1 (ICAM- 1) and mucosal addressin cell adhesion molecule-1 (MAdCAM-1) along with leukocyte $\alpha 4 \beta 1 \& \alpha 4 \beta 7$ expression and $\beta 2$ integrins which are released during inflammation and they act as primary mediators of leukocyte recruitment in colitis [27]. The dilated congested blood vessels was attributed to vasodilator substances released by the blood vessels into the blood stream causing vasodilatation and stagnation of blood leading to hypoxia of tissues which enhances secretion of nitric oxide. The latter relaxes the vascular smooth muscle cells leading to vasodilatation of blood vessels and more congestion and a vicious circle $[29,30]$.

The crypt distortion in the form of crypt dilatation and cyst formation in the lamina propria observed in this study was in agreement with the previous studies in which they described the cyst as a large, bulging, cystic dilation with a little "necklace" of cells around the crypt $[31,32]$. On the other hand, the crypt dilatation and cyst formation may be due to the interference of DSS with the normal interaction between intestinal lymphocytes, epithelial cells, and extracellular matrix and causes aberrant modulation of the expression of integrin $\beta 7$ receptors. In addition, it activates a transcription factor called nuclear factor kappa B (NF- $\kappa \mathrm{B})$ which is a key component in the inducible transcription of proinflammatory cytokines [31].

The decrease in goblet cells number may be due to excessive Interleukin 18 (IL-18) signaling on the epithelium which leads to progressive depletion of goblet cells. Interleukin 18 also inhibited goblet cell maturation by regulating the transcriptional program instructing goblet cell development.
These results inform on the mechanism of goblet cell dysfunction that underlies the pathology of ulcerative colitis [33]. In addition, the TNF- $\alpha$ resulted in loss of mucin inside goblet cells, decreasing colonic mucous layer thickness and exposing colonic mucosa to luminal antigens with more colonic mucosal inflammation [24]

Results of immunohistochemical COX-2 in this study showed statistically highly significant increase in the color intensity of immune reaction in the ulcerative colitis (DSS) group, this result was attributed to the COX-2 responsibility of production of prostaglandins E2 (PGE2) associated with the mediation of inflammation $[34,35]$.

Prostaglandin E2 is an important mediator of fever, pain, and inflammation. In addition endogenous prostaglandins (PGs) are actively involved in the mucosal defense against colonic ulceration and reduce the severity of DSS induced colitis by suppressing the induction of proinflammatory cytokines. The prostaglandin E2 receptor 4 (EP4) is one of four receptor subtypes for prostaglandin E2 that belongs to the family of $G$ protein-coupled receptors. It is widely distributed in the body especially the gastrointestinal tract. It has an antiinflammatory action on mononuclear cells and $\mathrm{T}$ cells, upregulates the anti-inflammatory cytokine IL-10, decreases apoptosis in the epithelium of colon, prevents goblet cell depletion, and promotes epithelial regeneration in inflammatory bowel disease and in rats with DSS-induced colitis $[36,37]$

In this study ultrastructural examination of the DSS group revealed shrunken columnar cells with electron dense cytoplasm. Shrunken cells may be due to atrophy by decrease in size of cells that have gained full development. It represents adaptation to a changed cellular environment. Cells shrink when their level of work is diminished or when their source of nutrition or stimulation is removed. The atrophic cells are small with their cytoplasmic organelles are fewer in number and size and their nuclei are small and in an eccentric position. The appearance of electron dense cytoplasm in atrophic cells may be due to the presence of denatured proteins, cytoplasmic debris, and degraded cytoplasmic organelles that collapse into dark amorphous mass [38]

Widening of the intercellular spaces seen in the current study was due to affection of the capillary endothelium at sites of injury with leakage of fluid into interstitial spaces isolating cells from one another. While vacuolated cytoplasm of the columnar cells was due to cell injury that moves water 
rapidly into cells and distorts the endoplasmic reticulum and Golgi apparatus in the cytoplasm. Massive accumulation of water which occurs in severe acute injury helps in forming large coalesced vacuoles [38]

Goblet cells appeared during current work with electron dense indented nuclei with apparent decrease in amount of mucin granules and dilated rER in their cytoplasm. This result was attributed to the misfolding assembly of mucin in goblet cells causing substantial Endoplasmic Reticulum (ER) stress, premature goblet cell apoptosis that progress to intestinal inflammation [39]. In addition, the secretory cells like goblet cells have relatively high rate of protein misfolding which is aggravated by ROS leading to ER stress [40].

Light and electron microscopic examination of sections treated with royal jelly \& DSS revealed the protective effect of royal jelly on ulcerative colitis which might be due to the anti-inflammatory and antioxidant properties of royal jelly [41-44].

Royal jelly contains a major fatty acid component (10H2DA) that inhibit lipopolysaccharide (LPS)-induced IL-6 production and LPS-induced NF- $\mathrm{KB}$ activation in a dose-dependent fashion, but did not inhibit TNF- $\alpha$ production, also 10H2DA can inhibit NF- $\mathrm{KB}$ activation via suppressing Nitric Oxide (NO) production and I $\mathrm{\kappa B}-\perp$ (inhibitor of $\mathrm{NF}-\kappa \mathrm{B}-\perp)$ mRNA expression and transcription stimulated by LPS and interferon (3 (IFN-(3) [45,46] On the other hand, the anti-inflammatory activity of royal jelly may be due to Adenosine N1-Oxide (ANO), which is also found in royal jelly components [47]

Royal jelly has antioxidant effect as it decreases the level of oxidative stress markers as glutathione and malondialdehyde [47]. In addition, it has hepatoprotective and antioxidant activities against carbon tetrachloride (CCl4)-induced acute liver damage [48]. Also the royal jelly has anti-oxidative effects on injury of the kidney and liver induced by cisplatin $[49,50]$. The antioxidant effects of royal jelly on radiation induced oxidative damage was attributed to the antioxidant capacity and free radical scavenging ability of royal jelly which is mainly due to its protein fractions and its polyphenolic compounds including flavonoids which are known to counteract oxidative stress by acting as powerful natural antioxidants [51].

\section{Conclusion:}

Based on the current study and from all previously mentioned histological, immunohistochem- ical and statistical results, it could be concluded that royal jelly has a protective effect on acute attacks of ulcerative colitis.

\section{References}

1- GEARRY R.B.: "IBD and Environment: Are There Differences between East and West." Dig. Dis., 34 (1-2): 84 9, 2016.

2- CONRAD K., D. ROGGENBUCK and M.W. LAASS: "Diagnosis and classification of ulcerative colitis." Autoimmun. Rev., 13 (4-5): 463-6, 2014.

3- ROGLER G.: "Chronic ulcerative colitis and colorectal cancer." Cancer Lett., 345 (2): 235-41, 2014.

4- MONTELEONE G., M.F. NEURATH, S. ARDIZZONE, A. Di SABATINO, M.C. FANTINI, F. CASTIGLIONE, et al.: "Mongersen, an oral SMAD7 antisense oligonucleotide, and Crohn's disease." N. Engl. J. Med., 372 (12): 1104-13, 2015.

5- BAMIAS G., T.T. PIZARRO and F. COMINELLI: "Pathway-based approaches to the treatment of inflammatory bowel disease." Transl. Res., 167 (1): 104-15, 2016.

6- KRISHNAN M., R.L. JAYARAJ, J. MEGALA and N. ELANGOVAN: "Antioxidant mediated antiulcer effect of Eupatorium triplinerve Vahl against acetic acid induced ulcerative colitis in mice." Biomedicine \& Aging Pathology, 4 (2): 153-60, 2014.

7- EL-MORSY E.M., R. KAMEL and M.A. AHMED: "Attenuating effects of coenzyme Q10 and amlodipine in ulcerative colitis model in rats." Immunopharmacol Immunotoxicol, 37 (3): 244-51, 2015.

8- MASSIRONI S., R.E. ROSSI, F.A. CAVALCOLI, S. DELLA VALLE, M. FRAQUELLI and D. CONTE: "Nutritional deficiencies in inflammatory bowel disease: Therapeutic approaches." Clin. Nutr., 32 (6): 904-10, 2013.

9- KRISHNAREDDY S. and A. SWAMINATH: "When combination therapy isn't working: Emerging therapies for the management of inflammatory bowel disease." World J. Gastroenterol., 20 (5): 1139-46, 2014.

10- ALVAREZ-SUAREZ J.M.: Bee Products-Chemical and Biological Properties. Switzerland, Springer International Publishing, 2017.

11- SUSILOWATI H., K. MURAKAMI, H. YUMOTO, T. AMOH, K. HIRAO, K. HIROTA, T. MATSUO and Y. MIYAKE: "Royal Jelly Inhibits Pseudomonas aeruginosa Adherence and Reduces Excessive Inflammatory Responses in Human Epithelial Cells." Biomed. Res. Int., 2017: 3191752, 2017.

12- LAROUI H., S.A. INGERSOLL, H.C. LIU, M.T. BAKER, S. AYYADURAI, M.A. CHARANIA, et al.: "Dextran sodium sulfate (DSS) induces colitis in mice by forming nano-lipocomplexes with medium-chain-length fatty acids in the colon." PLoS One, 7 (3): e32084, 2012.

13- WIRTZ S., V. POPP, M. KINDERMANN, K. GERLACH, B. WEIGMANN, S. FICHTNER-FEIGL, et al.: "Chemically induced mouse models of acute and chronic intestinal inflammation." Nat. Protoc., 12 (7): 1295-309, 2017.

14- VETUSCHI A., G. LATELLA, R. SFERRA, R. CAPRILLI and E. GAUDIO: "Increased proliferation and apoptosis 
of colonic epithelial cells in dextran sulfate sodiuminduced colitis in rats". Dig. Dis. Sci., 47 (7): 1447-57, 2002.

15- The National Research Council of the National Academies: Environment, housing and management (3) in Guide for Care and Use of the Laboratory Animals, eighth edition, National Academy of Sciences, Washington, USA, P 41, 2011.

16- GHANBARI E., V. NEJATI, G. NAJAFI, M. KHAZAEI and M. BABAEI: "Study on the effect of royal jelly on reproductive parameters in streptozotocin-induced diabetic rats". Int. J. Fertil Steril, 9 (1): 113-20, 2015.

17- UNAL B., H. TAN, Z. ORBAK, I. KIKI, M. BILICI, N. BILICI, et al.: "Morphological alterations produced by zinc deficiency in rat sciatic nerve: A histological, electron microscopic, and stereological study". Brain Res., 1048 (1-2): 228-34, 2005.

18- KIM SUVARNA C.L. and JOHN D. BANCROFT: Bancroft's Theory and Practice of Histological Techniques. British Library Cataloguing, Elsevier Limited, P.: 175238, 2013.

19- DAVIES H. and CROMBIE L.: What are confidence intervals and p-values?, Second edition, Hayward Group Ltd, P.: 1-6, 2009.

20- YAO J., J.Y. WANG, L. LIU, Y.X. LI, A.Y. XUN, W.S. ZENG, et al.: "Anti-oxidant effects of resveratrol on mice with DSS-induced ulcerative colitis". Arch. Med. Res., 41 (4): 288-94, 2010.

21- CHEAH K.Y., S.E. BASTIAN, T.M. ACOTT, S.M. ABIMOSLEH, K.A. LYMN and G.S. HOWARTH: "Grape seed extract reduces the severity of selected disease markers in the proximal colon of dextran sulphate sodiuminduced colitis in rats". Dig. Dis. Sci., 58 (4): 970-7, 2013.

22- FAROMBI E.O., I.A. ADEDARA B.O. AJAYI O.R. AYEPOLA and E.E. EGBEME: "Kolaviron, a natural antioxidant and anti-inflammatory phytochemical prevents dextran sulphate sodium-induced colitis in rats". Basic Clin. Pharmacol. Toxicol., 113 (1): 49-55, 2013.

23- CHASSAING B., J.D. AITKEN, M. MALLESHAPPA and M. VIJAY-KUMAR: "Dextran sulfate sodium (DSS)induced colitis in mice". Curr. Protoc. Immunol., 104: Unit 15.25, 2014.

24- BALAHA M., S. KANDEEL and W. ELWAN: "Garlic oil inhibits dextran sodium sulfate-induced ulcerative colitis in rats". Life Sci., 146: 40-51, 2016.

25- GAO F. and T. HORIE: "A synthetic analog of prostaglandin $\mathrm{E}(1)$ prevents the production of reactive oxygen species in the intestinal mucosa of methotrexate-treated rats". Life Sci., 71 (9): 1091-9, 2002.

26- NAGIB M.M., M.G. TADROS, M.I. EL-SAYED and A.E. KHALIFA: "Anti-inflammatory and anti-oxidant activities of olmesartan medoxomil ameliorate experimental colitis in rats". Toxicol. Appl. Pharmacol., 271 (1): 106-13, 2013.

27- ABDELBAQI M., J.H. CHIDLOW, K.M. MATTHEWS, K.P. PAVLICK, S.C. BARLOW, A.J. LINSCOTT, et al.: "Regulation of dextran sodium sulfate induced colitis by leukocyte beta 2 integrins". Lab. Invest., 86 (4): 380-90, 2006.
28- CHAUDHARY G., U.B. MAHAJAN, S.N. GOYAL, S. OJHA, C.R. PATIL and S.B. SUBRAMANYA: "Protective effect of Lagerstroemia speciosa against dextran sulfate sodium induced ulcerative colitis in C57BL/6 mice". Am. J. Transl. Res., 9 (4): 1792-800, 2017.

29- DEHLER M., E. ZESSIN, P. BARTSCH and H. MAIRBAURL.: "Hypoxia causes permeability oedema in the constant-pressure perfused rat lung". Eur. Respir. J., 27 (3): 600-6, 2006.

30- LUNDGREN J. and G. RADEGRAN: "Pathophysiology and potential treatments of pulmonary hypertension due to systolic left heart failure". Acta. Physiol. (Oxf), 211 (2): 314-33, 2014.

31- KULLMANN F., H. MESSMANN, M. ALT, V. GROSS, T. BOCKER, J. SCHÖLMERICH, et al.: "Clinical and histopathological features of dextran sulfate sodium induced acute and chronic colitis associated with dysplasia in rats". International Journal of Colorectal Disease, 16 (4): 238-46, 2001.

32- SACHAR D.B.: "What Is the Role for Endoscopy in Inflammatory Bowel Disease?" The American Journal of Gastroenterology, 102 (s1): S29-s31, 2007.

33- NOWARSKI R., R. JACKSON, N. GAGLIANI, M.R. De ZOETE, N.W. PALM, W. BAILIS, et al.: "Epithelial IL-18 Equilibrium Controls Barrier Function in Colitis". Cell, 163 (6): 1444-56, 2015.

34- SINGER I.I., D.W. KAWKA, S. SCHLOEMANN, T. TESSNER, T. RIEHL and W.F. STENSON: "Cyclooxygenase 2 is induced in colonic epithelial cells in inflammatory bowel disease". Gastroenterology, 115 (2): 297 306, 1998.

35- PAIOTTI A.P., R. ARTIGIANI NETO, N.M. FORONES, C.T. OSHIMA, S.J. MISZPUTEN and M. FRANCO: "Immunoexpression of cyclooxygenase- 1 and -2 in ulcerative colitis". Braz. J. Med. Biol. Res., 40 (7): 911-8, 2007.

36- OKAYAMA M., S. HAYASHI Y. AOI, H. NISHIO, S. KATO and K. TAKEUCHI: "Aggravation by selective COX-1 and COX-2 inhibitors of dextran sulfate sodium (DSS)-induced colon lesions in rats". Dig. Dis. Sci., 52 (9): 2095-103, 2007.

37- YOKOYAMA U., K. IWATSUBO, M. UMEMURA, T. FUJITA and Y. ISHIKAWA: "The prostanoid EP4 receptor and its signaling pathway". Pharmacol. Rev., 65 (3): 101052, 2013.

38- CHEVILLE N.F.: Structural Basis of Cell Injury. Ultrastructural Pathology The Comparative Cellular Basis of Disease. N.F. Cheville. Singapore., A John Wiley \& Sons: 5-288, 2009.

39- HEAZLEWOOD C.K., M.C. COOK, R. ERI, G.R. PRICE, S.B. TAURO, D. TAUPIN, et al.: "Aberrant mucin assembly in mice causes endoplasmic reticulum stress and spontaneous inflammation resembling ulcerative colitis". PLoS Med., 5 (3): e54, 2008.

40- HASNAIN S.Z., R. LOURIE, I. DAS, A.C. CHEN and M.A. McGUCKIN: "The interplay between endoplasmic reticulum stress and inflammation". Immunol. Cell. Biol., 90 (3): 260-70, 2012.

41- KARACA T., F. BAYIROGLU, M.U. YORUK, S. KAYA, S. USLU, B. COMBA, et al.: "Effect of royal jelly on 
experimental colitis Induced by acetic acid and alteration of mast cell distribution in the colon of rats". European Journal of Histochemistry, 54 (4): 35, 2010.

42- YANAGITA M., Y. KOJIMA, K. MORI, S. YAMADA and S. MURAKAMI: "Osteoinductive and antiinflammatory effect of royal jelly on periodontal ligament cells". Biomed. Res., 32 (4): 285-91, 2011.

43- KARACA T., Y.H. UZ, S. DEMIRTAS, I. KARABOGA and G. CAN: "Protective effect of royal jelly in 2, 4, 6 trinitrobenzene sulfonic acid-induced colitis in rats". Iran J. Basic Med. Sci., 18 (4): 370-9, 2015.

44- MANZO L.P., F.M. De-FARIA, R.J. DUNDER, E.A. RABELO-SOCCA, S.R. CONSONNI, A.C. De ALMEIDA, et al.: "Royal Jelly and its dual role in TNBS colitis in mice". Scientific World Journal, 2015: 956235, 2015.

45- SUGIYAMA T., K. TAKAHASHI, S. TOKORO, T. GOTOU, P. NERI and H. MORI: "Inhibitory effect of 10-hydroxy-trans-2-decenoic acid on LPS-induced IL-6 production via reducing IkappaB-zeta expression". Innate Immun., 18 (3): 429-37, 2012.

46- SUGIYAMA T., K. TAKAHASHI, A. KUZUMAKI, S. TOKORO, P. NERI and H. MORI: "Inhibitory mechanism of 10-hydroxy-trans-2-decenoic acid (royal jelly acid) against lipopolysaccharide- and interferon-beta-induced nitric oxide production". Inflammation, 36 (2): $372-8$, 2013.

47- KOHNO K., E. OHASHI, O. SANO, H. KUSANO, T. KUNIKATA, N. ARAI, et al.: "Anti-inflammatory effects of adenosine N1-oxide". J. Inflamm. (Lond), 12 (1): 2, 2015 .

48- CEMEK M., F. AYMELEK, M.E. BUYUKOKUROGLU, T. KARACA, A. BUYUKBEN and F. YILMAZ: "Protective potential of Royal Jelly against carbon tetrachloride induced-toxicity and changes in the serum sialic acid levels". Food Chem. Toxicol., 48 (10): 2827-32, 2010.

49- KARADENIZ A., N. SIMSEK, E. KARAKUS, S. YILDIRIM, A. KARA, I. CAN, et al.: "Royal jelly modulates oxidative stress and apoptosis in liver and kidneys of rats treated with cisplatin". Oxid. Med. Cell Longev., 2011: 981793, 2011

50- SILICI S., O. EKMEKCIOGLU, M. KANBUR and K. DENIZ: "The protective effect of royal jelly against cisplatin-induced renal oxidative stress in rats". World J. Urol., 29 (1): 127-32, 2011.

51- AZAB K.S., M. BASHANDY, M. SALEM, O. AHMED, Z. TAWFIK and H. HELAL: "Royal jelly modulates oxidative stress and tissue injury in gamma irradiated male Wister Albino rats". N. Am. J. Med. Sci., 3 (6): 26876, 2011.

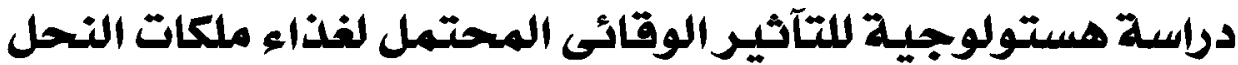

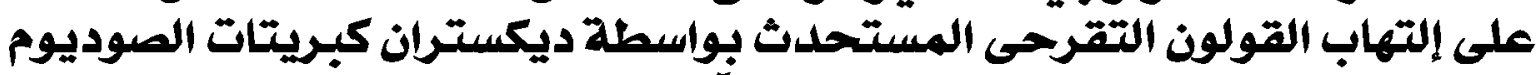 فى ذكر الجرذ الآبيض البالغ}

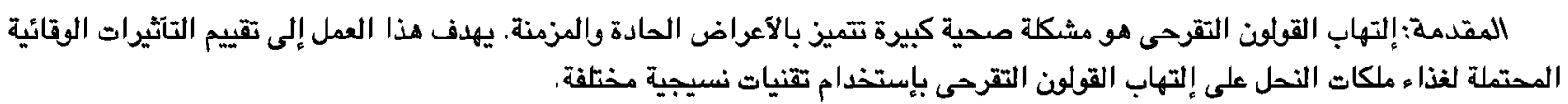

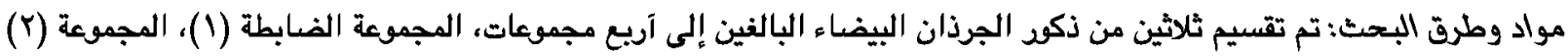

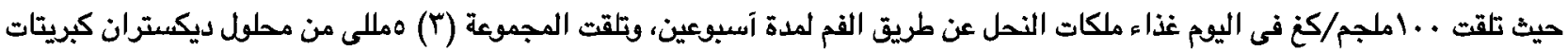

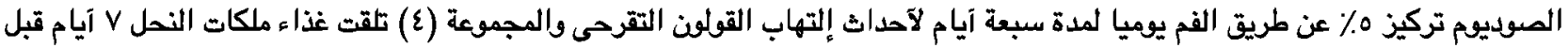

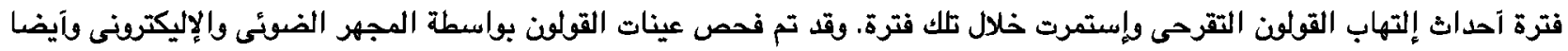

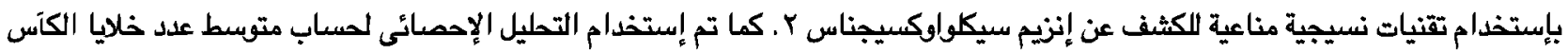
وثئدة لمن رد الفعل المناعى.

النتائج: كثف الفحص بالمجهر الضوئى لعينات المجنموعة (ب) تاكل فى خلايا العطع الظاهرية، وتسلل الخلايا الإلتهابية، وظهود إحتقان

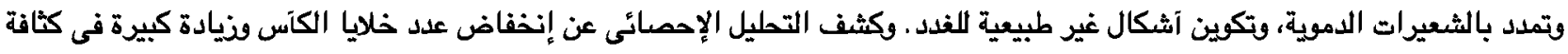

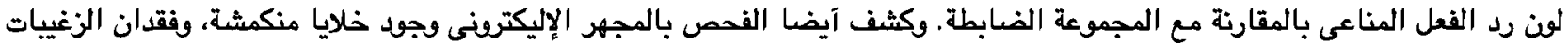

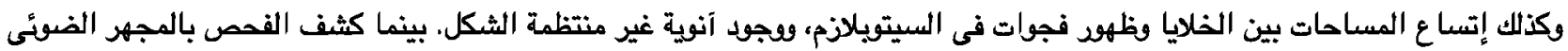

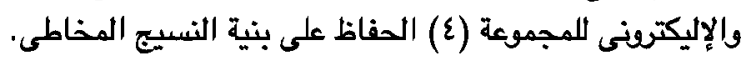
الإسبتستاج: غذاء ملكات النحل له تآثير جيد على تخفيف إلتهاب القولفن التقرحى الحاد. 